This item was submitted to Loughborough's Research Repository by the author.

Items in Figshare are protected by copyright, with all rights reserved, unless otherwise indicated.

\title{
Police authorities, accountability, and citizenship
}

PLEASE CITE THE PUBLISHED VERSION

http://dx.doi.org/10.1093/police/pas022

\section{PUBLISHER}

(c) The Author 2012. Published by Oxford University Press

\section{VERSION}

AM (Accepted Manuscript)

\section{LICENCE}

CC BY-NC-ND 4.0

\section{REPOSITORY RECORD}

Stephens, Mike, and Floyd Millen. 2019. "Police Authorities, Accountability, and Citizenship". figshare. https://hdl.handle.net/2134/15096. 
This item was submitted to Loughborough's Institutional Repository (https://dspace.lboro.ac.uk/) by the author and is made available under the following Creative Commons Licence conditions.

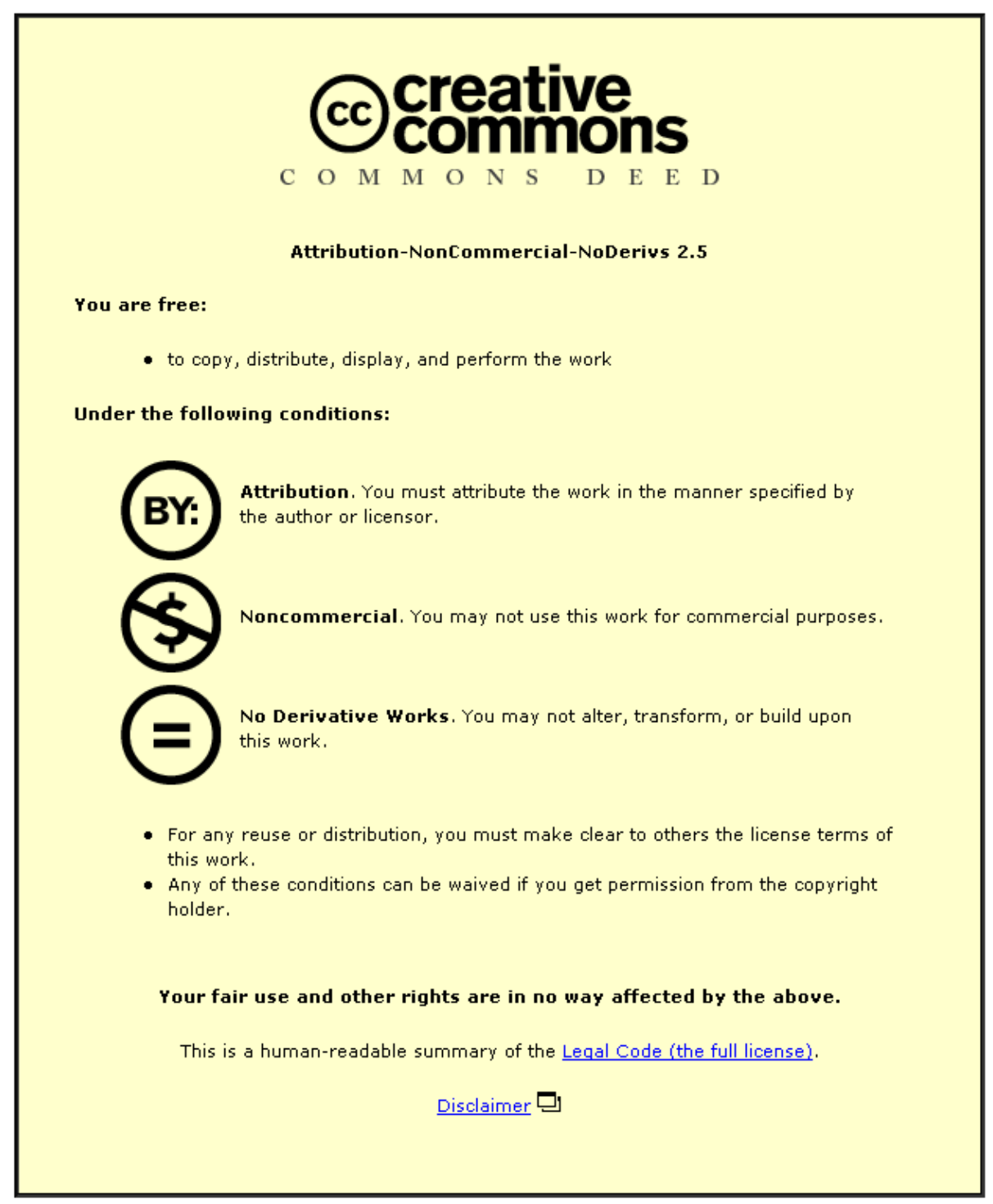

For the full text of this licence, please go to: http://creativecommons.org/licenses/by-nc-nd/2.5/ 


\title{
Police Authorities, Accountability and Citizenship
}

\author{
Dr. Floyd Millen and *Dr. Mike Stephens \\ Department of Social Sciences \\ Loughborough University \\ Loughborough, Leics. LE11 4BU. UK
}

*For correspondence - m.r.stephens@lboro.ac.uk

\section{Synopsis}

Policing has recently attracted a great deal of controversy set against the recent wave of student disturbances and the use of paramilitary tactics to disperse, contain and kettle protestors. Moreover, the controversial application of stop and search powers under the Terrorism Act 2000 has raised further questions about the accountability of the police.

The responsibility of holding the police to account currently falls to the 43 police authorities operating across England and Wales. This paper draws on ground-breaking research on police authorities using questionnaire and indepth interview data to outline just how it is that police authority members approach their duties and responsibilities. It outlines the role and potential of police authorities to influence police policy and operations and discusses how the work of police authorities has impacted on participation by local citizens. Our starting position is that citizen participation is a prerequisite for the effective delivery of accountable policing. This has serious consequences for the proposed Police and Crime Commissioners, which are intended to replace police authorities in the near future. 
Key Words: Police authorities, policing, accountability, citizenship.

\section{Introduction}

Police authorities are independent bodies. They have the responsibility to set the strategic direction for the local police force whilst simultaneously holding the chief constable to account for the policing service delivered. There is a police authority for each local police force - 43 in England and Wales.

The Police and Magistrates' Courts Act 1994 - which came into force on $1^{\text {st }}$ April 1995 - brought significant changes to both the composition and powers of police authorities in England and Wales. The act made police authorities independent of local government, reduced the numbers of elected councillors and introduced independent members for the first time. As a result of the act, police authority membership consisted of 9 local councillors, 5 independent or appointed members and 3 magistrate members totalling 17 members. Some larger authorities have slightly more members; for example the Metropolitan Police Authority has 23 members which enabled it to more adequately represent London's size and make up and the Greater Manchester Police Authority has 19 members. The Police and Justice Act (2007) changed the appointment process and the basis of police authority membership. As a result of the act, magistrate members cease to exist as a separate category although most police authorities continue to appoint magistrate members under the provision of the act which requires 'other persons, including at least one lay justice' (The Police and Justice Act (2007): Schedule 2, Section 4).

The role of police authorities was further re-defined under The Police Act 1996 which gave them specific additional responsibilities, including the requirement to publish local policing plans in consultation with local communities and other interest groups. The act also included the responsibility of monitoring performance, collecting and publishing 
performance information, producing efficiency and Best Value performance plans, delivering best value, accounting for the constabulary's finances, managing the constabulary's resources, planning and deciding budgets, investigating complaints against senior police officers and monitoring overall complaints procedures through to appointing chief police officers.

The Crime and Disorder Act (1998) created Crime and Disorder Reduction Partnerships (CDRP) under which police forces and local authorities, in cooperation with police authorities and other agencies, were required to consult the public on a local audit of crime and disorder and a strategy for tackling them. The onus for crime prevention became a joint responsibility between the police and local authorities. The Crime and Disorder Act 1998 provided the remit for partnerships to be inclusive of agencies and individuals in their area. There was however a fear that police authorities had a somewhat lesser role because a), local authorities had greater resources than police authorities, hence the expectation that local authorities would have a greater degree of influence over local policing priorities; and b), under The Crime and Disorder Act (1998) police authorities were not afforded the same status as local authorities or the police service. The passing of the Police Reform Act (2002) rectified this and police authorities were given the same status as police forces and local authorities on Crime and Disorder Reduction Partnerships (CDRP): in addition, police authorities were required to produce annual policing plans to consider the views of the local community. According to Jones and Newburn (1997) whilst the Police and Magistrates' Courts Act 1994 had already given police authorities sufficient powers, they argued that if police authorities worked in a seamless way with the chief of police there would be very little room for police authorities to be undermined or side-lined at the local level.

This situation could potentially arise because police authorities do not appear to impact (directly) on operational policing in the same way as the activities of 
the Crime Reduction Partnerships. At the end of their study of six police authorities, Jones and Newburn (1997) concluded that although chief police officers still dominated policy and the planning process, the Police and Magistrates' Courts Act 1994 gave police authorities' potential strength that was yet to be applied in full. They concluded that if police authorities worked in a seamless way with the chief constable then there would be very little room for the authority to be undermined or side-lined at local level.

As the bridge between local people and police forces, police authorities have a crucial role to play in building trust, gaining confidence and ensuring that the collective will is reflected in local policing. It is increasingly clear that they stand in a pivotal position and can - if they so desire - really influence the experience of policing - an experience in which the role of the citizen is crucial (Audit Commission, 2002, 2003a; Dalgleish, 2003:3; MORI, 2003; Coleman, 2005).

Our system of police accountability will only attract and retain public legitimacy if those who have this stewardship role to ensure increased accountability - police authorities and their members - fully understand and appreciate their roles, responsibilities and the mechanisms through which an account can be brought. What we have with police authorities and the tripartite system ${ }^{1}$ is an arrangement that is set up to facilitate transparency and a higher degree of accountability. However, in reality there appears to be insufficient access and knowledge of the process or the methods by which the citizen can influence policing and by which policing can be understood. According to some academics this confusion is intentional (Jones et al, 1994: 27).

\footnotetext{
${ }^{1}$ The tripartite system refers to the three-way governance arrangement of policing between the Home Secretary, Chief Constables and Police Authorities.
} 


\section{Representation, Trust and Accountability}

In general, there are low levels of public participation in the provision of services. The Audit Commission (2003a; 2003b) conducted research on accountability, public trust and confidence in public services and found that people trusted individuals much more than organisations because the notion of trust was based on relationship, familiarity and experience. The Audit Commission (2003a) rated the police as the worst of three services in providing information although the police was the institution that was seen as most likely to be controlled by an independent watchdog. The Audit Commission (2003a) found that, generally, public trust in local authorities was low and the reason that it was much lower in the police was primarily because the public did not think that the police would listen to their views and also that public awareness of the regulators was low. Preoccupation with the tripartite structure of accountability implicitly denies the place and importance of the citizen. It is important for the effective functioning of the police that we acknowledge that the tripartite system would be improved if it were a quartet of Home Secretary, chief constables, police authorities and citizens. Scarman $(1986,4.60)$ noted '.. . [the police] enforce the law on behalf of the community; indeed they cannot effectively enforce it without the support of the community'. The proposal by the coalition government to elect commissioners to replace police authorities is an attempt to address this issue (Police Reform and Social Responsibility Act, 2011).

Public awareness of police authorities is almost non-existent (Dalgleish, 2003; Myhill, 2003; Docking, 2003); in fact the recent announcements by the coalition government about police authorities and local accountability has done more for the profile of police authorities than almost anything in recent years. Public knowledge of the existence of police authorities is crucial if they are to be effective and have the credibility required to undertake their role: this will also be true for the newly elected commissioners for whom a higher 
level of accountability, public engagement and results will be required (Police Reform and Social Responsibility Act, 2011).

Calls for greater public accountability dictate that an institution has:

a) Sufficient expertise,

b) Adequate knowledge of its role and the mechanisms of leverage,

c) That there are checks and balances to negate undue influence and

d) That the institution has the resource capability to deliver (Pyper,1996:3).

For police authorities, many of the above requirements have been met. For example, police authorities arguably have the basic structural framework, resources and relevant powers to enable them to perform their functions. They have responsibility for setting the police budget; they have the additional resources and expertise of their members. There is also the appointment of civil staff (or secretariat) whose role it is to support the appointed members in their work for the authority. Both police authority members and the civil staff work closely with the local police force to produce local policing plans and the chief constable reports on a monthly basis to the authority on the activities of the force.

However, there have been increasing calls to strengthen police authorities because of the shift of power away from police authorities to the Home Office and chief constables (Jones and Newburn, 1994)). The effect of this is that there are few checks and balances in the system not only because police authorities and its members have insufficient knowledge about what it is that they and the authority ought to be doing, but also because they lack the formal powers they need to exert real influence. Our research supports the findings of Jones and Newburn (1997) who found that police authorities were increasingly preoccupied with organisational issues rather than the strategic policy issues governing local policing. On this basis, it is clear that police authorities have 
little real control and are unable to effectively bring chief constables and their police services to account in any meaningful way.

\section{Methodology}

At the time of our research there are approximately 760 police authority members in the 43 police authorities in England and Wales. In late 2007 questionnaire surveys were sent to all police authorities and initially 81 were returned. In January 2008 a further 200 questionnaires were sent out and a further 27 completed questionnaires were received, totalling 108 (14.2\%). Some police authorities have generic email addresses where all correspondence is filtered to the police authority member by Member Services. However, where direct contact details were available the questionnaire was sent directly to individual police authority members. Some police authorities such as Hertfordshire Police Authority have a designated member to respond on behalf of the police authority. While the total number of respondents that returned completed questionnaires was 108, the total number of responses for each question varies considerably as some respondents provided multiple answers to some questions.

New empirical ground has been covered by this research, as the literature reveals no similar survey which has focused on police authority members. In addition, 24 semi-structured, in-depth interviews were conducted with specific individuals who are significant gatekeepers between the community, the police service and the police authority. Interviewees included 17 police authority members, a former Home Secretary, the Chairman of the Association of Police Authorities, the Executive Director of the Association of Police Authorities, the Policy Officer of the Association of Police Authorities, the Clerk to the Metropolitan Police Authority, a former chief constable and a grade 5 civil servant. 
Between 1964 and 1994 there has been a small body of work on police authorities (Jones \& Newburn, 1997; Brogden, 1977; Reiner, 1991). This paper sets out the most recent academic work on police authorities and is the only empirical academic work to look at the role of police authorities in the context of citizenship and accountability.

The findings of the research shed light on the following:

a) The relevancy of police authorities, their potential and their actual impact.

b) The role of police authorities in relation to the citizen, the police service and accountability.

c) The views of police authority members on how they perceive their role and the role of the police authority.

\section{Findings}

This research has shown that 68 out of the 126 (54\%) responses by police authority members to the question of responsibility accepted that the police authority was ultimately responsible for policing in their area and as far as responsibility was concerned they ranked the police service and the Home Office in second (29) and third (21) place respectively (Fig.1). 
Figure.1 Who is ultimately responsible for policing?

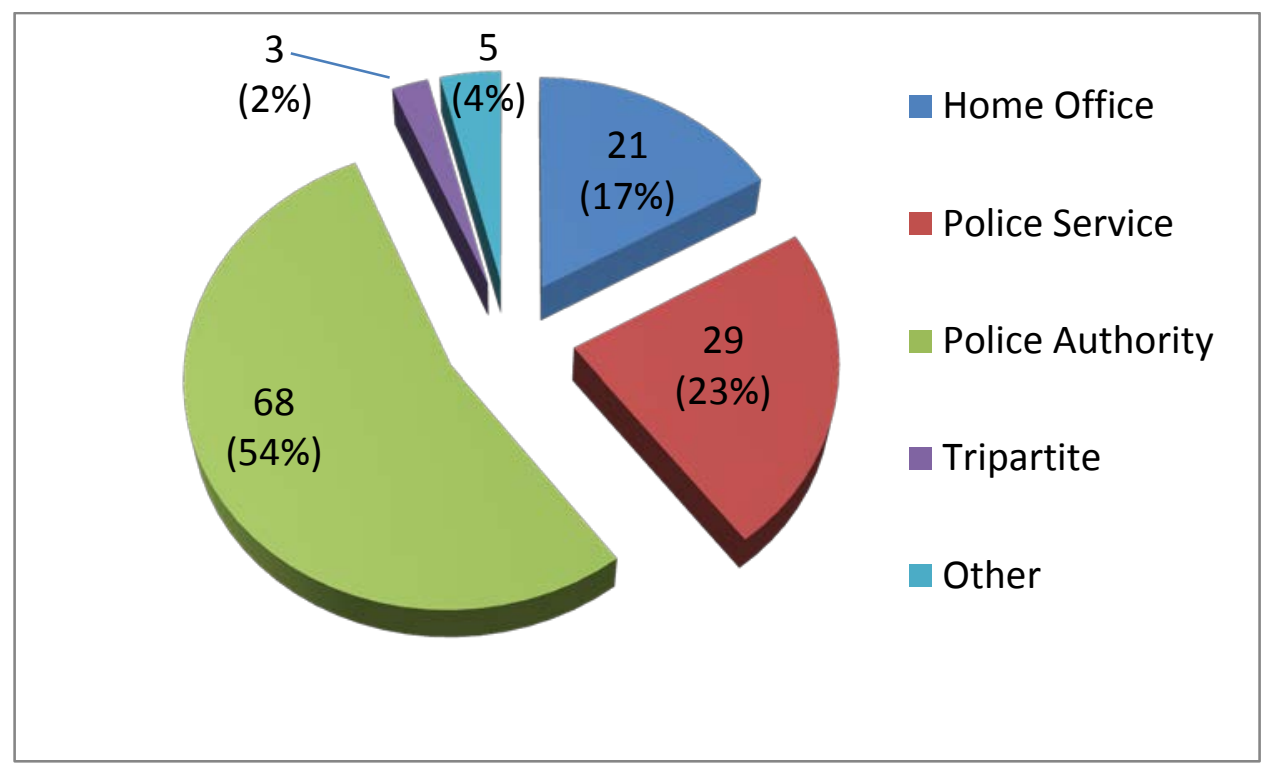

The question of 'who is ultimately responsible for policing' was - in effect - a statement of duty rather than legal responsibility. Whilst members accepted that responsibility for policing ultimately lay with them as police authority members, further analysis of the responses reveals a clear disconnection between the perceived balance of responsibility (Fig.1), the right to make final decisions in disputes (Fig.2) and the perceived possession of power (Fig.3). Responses to Figure. 3 show that whilst members felt the police authority had the least power within the tripartite system, they perceived that it had the most responsibility. This viewpoint was further reinforced when members responded to the question: "who they thought had the final decision in disputes?" (Fig.2). The overwhelming view was that the Home Secretary clearly had the final decision. In-depth interviews with police authority members shed further interesting light on this issue. One independent member of North Wales Police Authority forcibly emphasised during the interview that wherever the power and final decision lay, it was most definitely not with the police authority. He explained: 
'... I sometimes ask in a meeting - and publicly - if we vote against this [action, policy or direction] what will happen? and the answer is that it will go ahead anyway!'

Figure.2 In disputes who has the final decision?

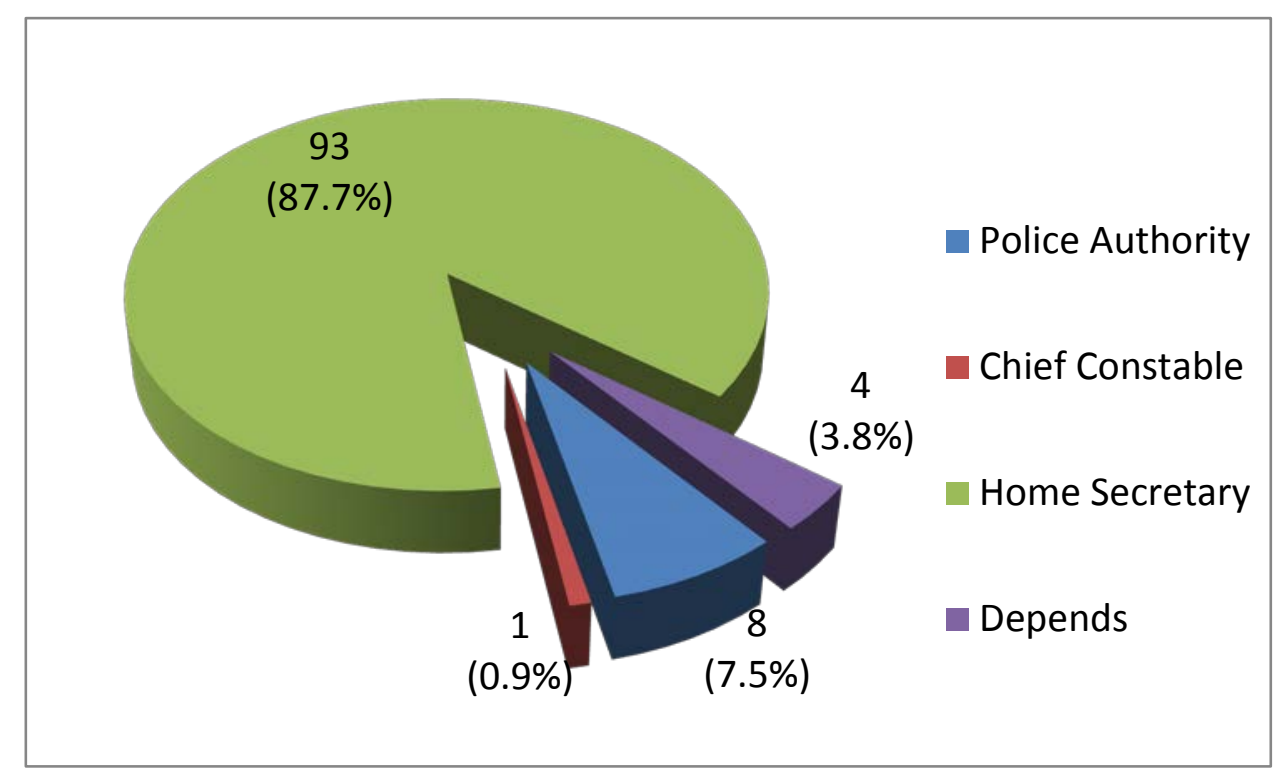

Fig. 2 shows that the vast majority of the sample believe that the Home Secretary has the final decision in disputes. Fig. 3 also provides contemporary support to the position expounded by Reiner (1991) that the Home Secretary and chief constable hold the balance of power. According to Reiner (2000) and Brogden (1977) in cases of real conflict between a chief constable and a police authority not only would the chief constable always prevail but the police authority would defer to the expertise of the chief. 
Figure.3 Where does the balance of power reside?

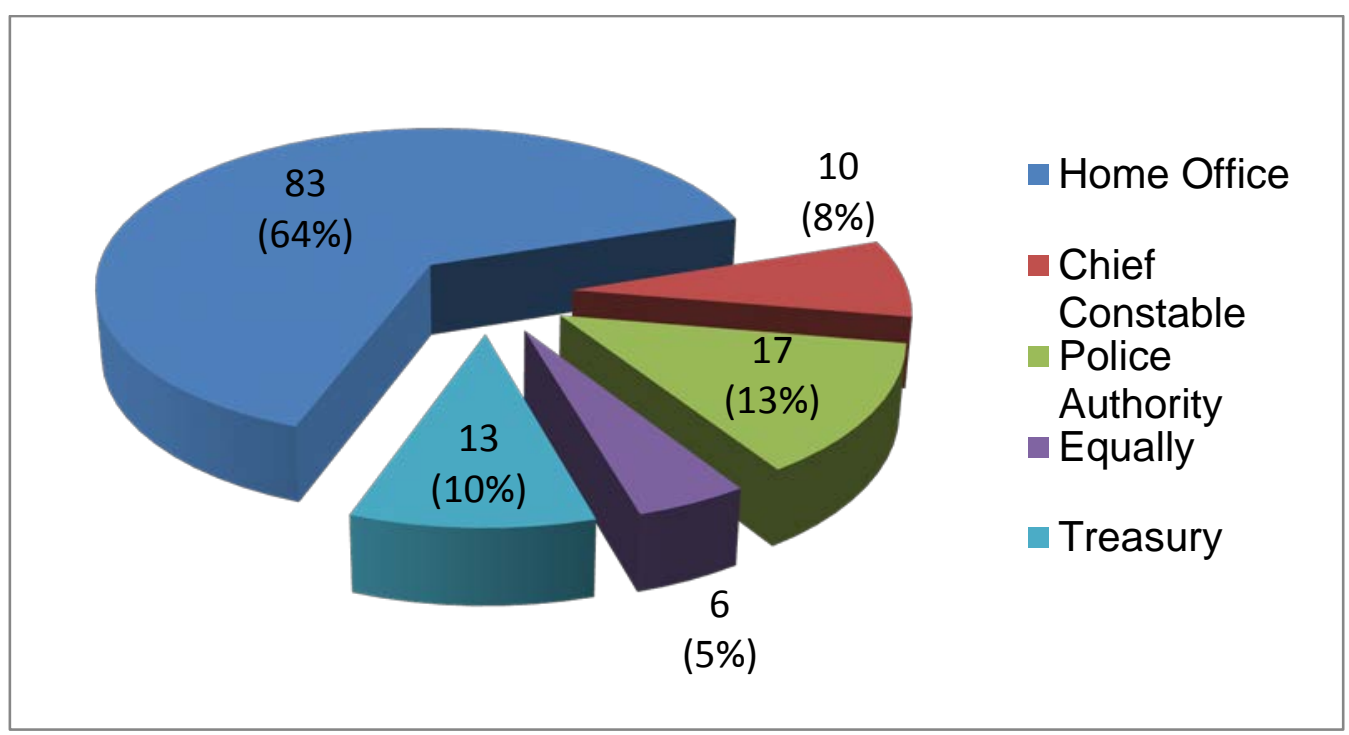

The former Home Secretary Rt Hon Charles Clarke MP saw the balance of power as primarily residing with the chief constable and saw that the onus was on the police authority to find a way to work with the chief of police whom he saw as controlling operational policing. An independent member of North Wales Police Authority felt that the relationship was '...more about influence rather than power' which suggested that far from the 'self-limiting' description of Jones et al (1994: 62), the police authority was able to exercise its influence through a more complex process of negotiation rather than through the overt display of power. 
Figure.4 Within the tripartite system is the police authority proactive or reactive?

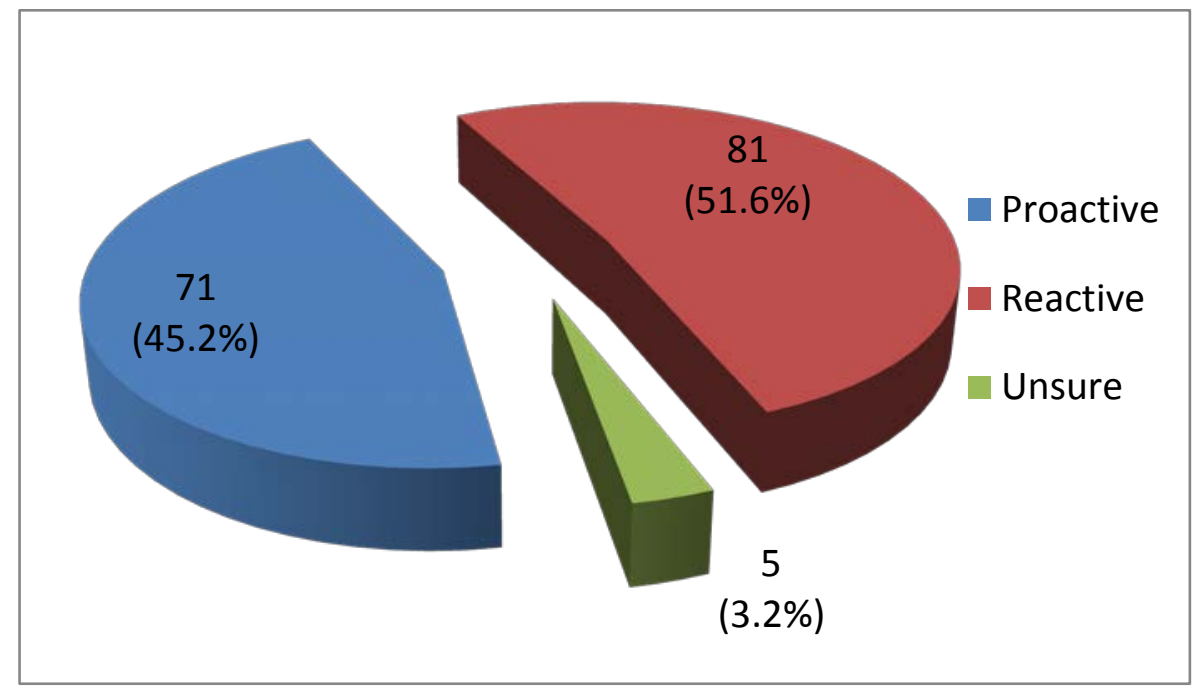

On the question of whether members thought their police authority was proactive or reactive, Fig. 4 shows that over 81 of the 157 responses indicated their belief that the police authority was more reactive than proactive. Despite this, an independent member of the Metropolitan Police Authority argued that in order to effectively fulfil its role police authorities had to be proactive. A councillor member of Sussex Police Authority explained that as a police authority Sussex tried to be proactive but '... at the end of the day we are lay people and are not involved 24 hours a day, seven days a week.' Other interviewees also echoed this and saw their police authorities as more reactive than proactive. Typical of this view was the following: '...there is a degree of inevitability because just in terms of energy and resources there is a squad of people [police and civil staff] paid and working fulltime... this is where the power lies.' 
Figure.5 Who do members represent?

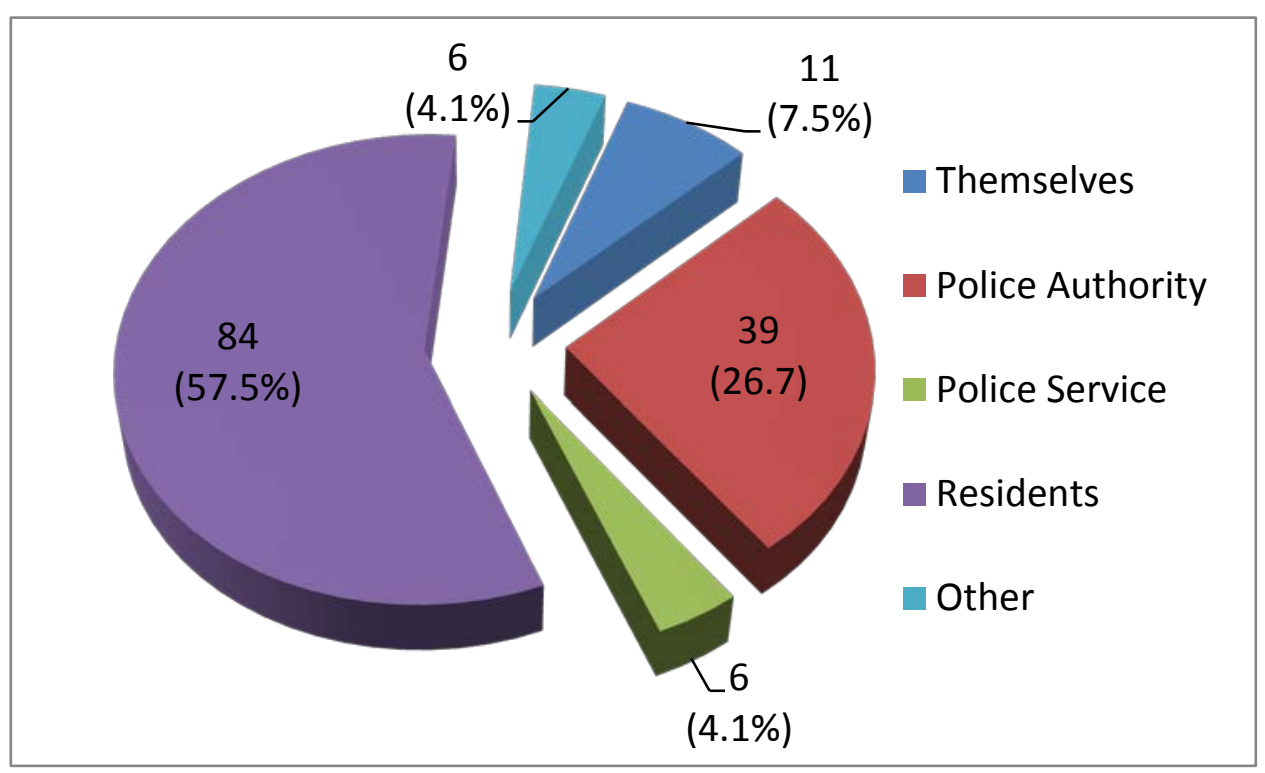

Eighty four members (Fig.5) saw themselves as primarily representing the residents in their local areas while 39 saw that they had a responsibility to represent the police authority. In order for police authorities to be effective there needs to be a balance between the responsibilities of members to represent and consult with local people - which is a responsibility given to police authorities under the Police and Criminal Evidence Act (1984), the Police and Magistrates Courts Act (1994) and the Crime and Disorder Act (1998) - and the responsibility of the police authority under the provision of the Police Act (1964) (section 4.1) 'to secure the maintenance of an adequate and efficient police force for the area'. The job description for police authority members clearly reflects this aspiration stating that members are appointed to fulfil a dual role; '.. to represent the views of the police authority within local communities and the views of local communities to the authority' (Leicestershire Police Authority, 2007). 
Figure.6 Are members doing enough to represent those identified in

Figure.5?

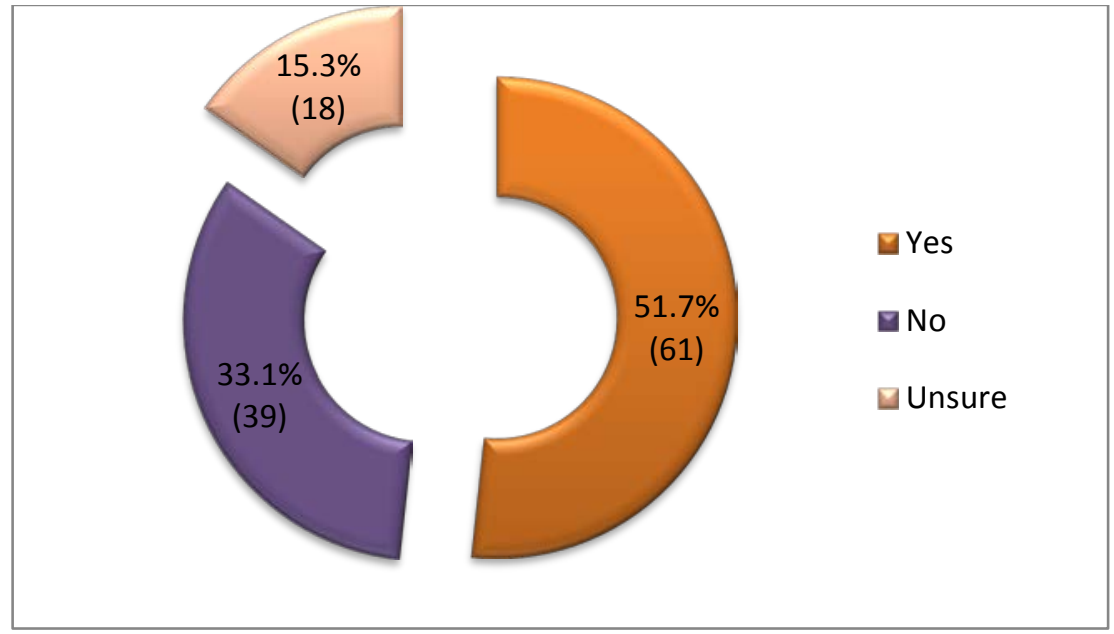

Figure.7 Is the police authority doing enough to represent its constituents?

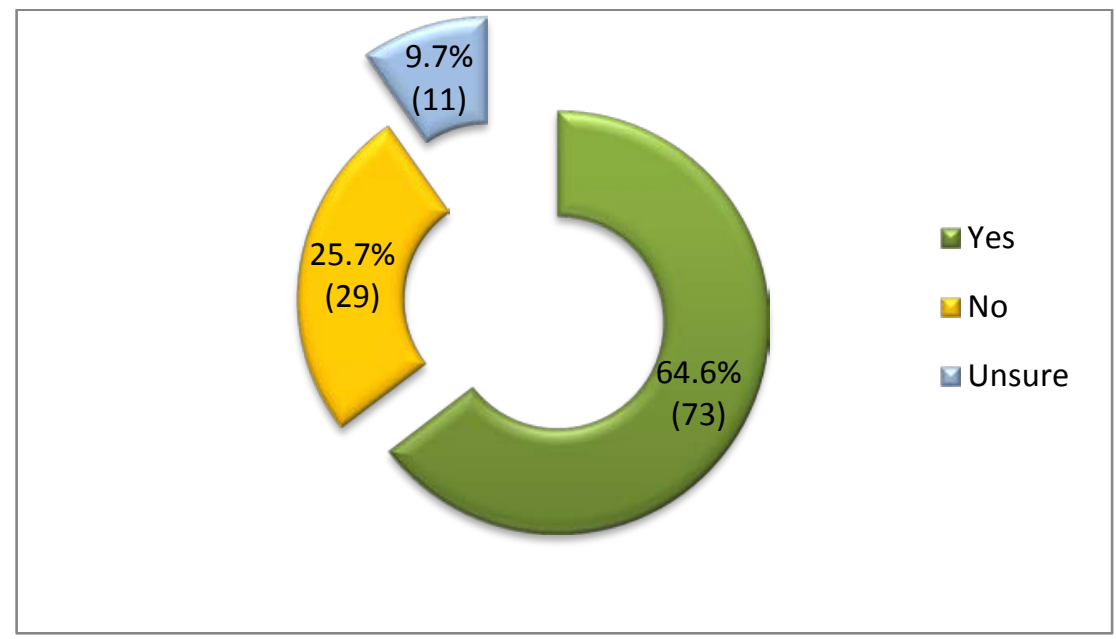

On the question of whether police authorities were doing enough to represent residents, the police service and the wider community, 73 responses (Fig.7) indicated that members thought their police authority was doing enough. Even though 61 responses (Fig.6) indicated that members felt that they and other members like themselves were doing enough to represent those they had identified in Fig.5, 39 members (Fig.6) indicated that as members they 
were not doing enough whilst 18 were unsure about whether they were doing enough to represent effectively.

At the heart of the question of whether police authority members are doing enough to represent the interests of those who depend on them is the question of whether members know how to bring the chief constable to account and more specifically what questions to ask. This research supports the findings of Day \& Klein (1987) that police authority members lack sufficient knowledge and understanding, resulting in them being unable to ask the right questions; it supports Jones and Newburn's (1994) findings about the confusing relationship between members of the tripartite system; it supports the findings of Stephens (1988) that police authority budgetary powers were not effective as a means of influence and, finally, our research supports Hewitt (1996) who saw police authorities as performing housekeeping functions and Reiner (1992) who saw police authorities as largely ineffective. One Metropolitan Police Authority member explained that in her experience,

'... in order to know what questions to ask you read a lot! The commissioner is at our behest and we know what to ask by doing our own research in the same way journalists do. If we attend meetings and expect things to be handed to us we are not doing our job.'

A councillor member of Sussex Police Authority and a councillor member of North Yorkshire Police Authority both argued that local knowledge and experience were vital if members were to be effective and to know what to ask.

An independent member of North Wales Police Authority explained that members are appointed not as experts but because they have been 'round the block' and the variety of experience that comes to the authority 
particularly from those with public sector experience is considerable. This response implies that members are pragmatic and aware that their scope of effectively holding the police to account is potentially restricted by the resource and time implications that go along with the terms of their appointment.

Figure.8 How effective are Community Police Consultative Groups (CPCG)?

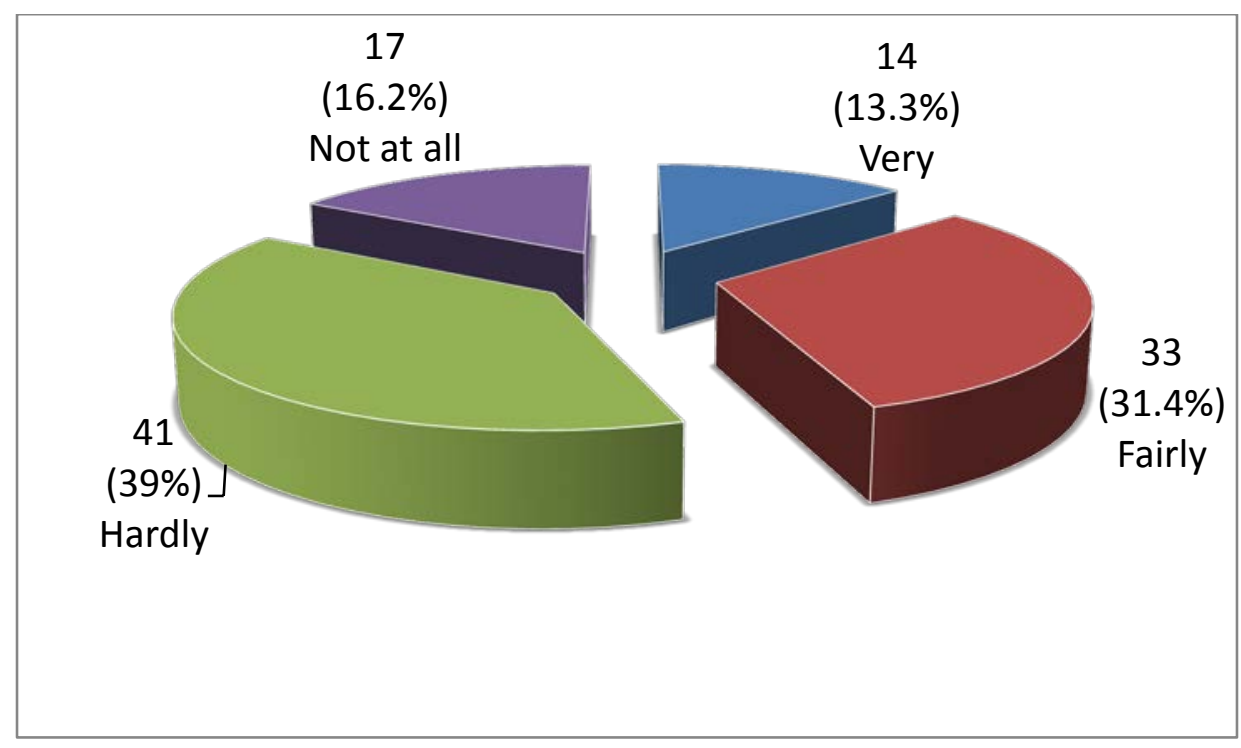

Figure.9 Do they attract a representative audience?

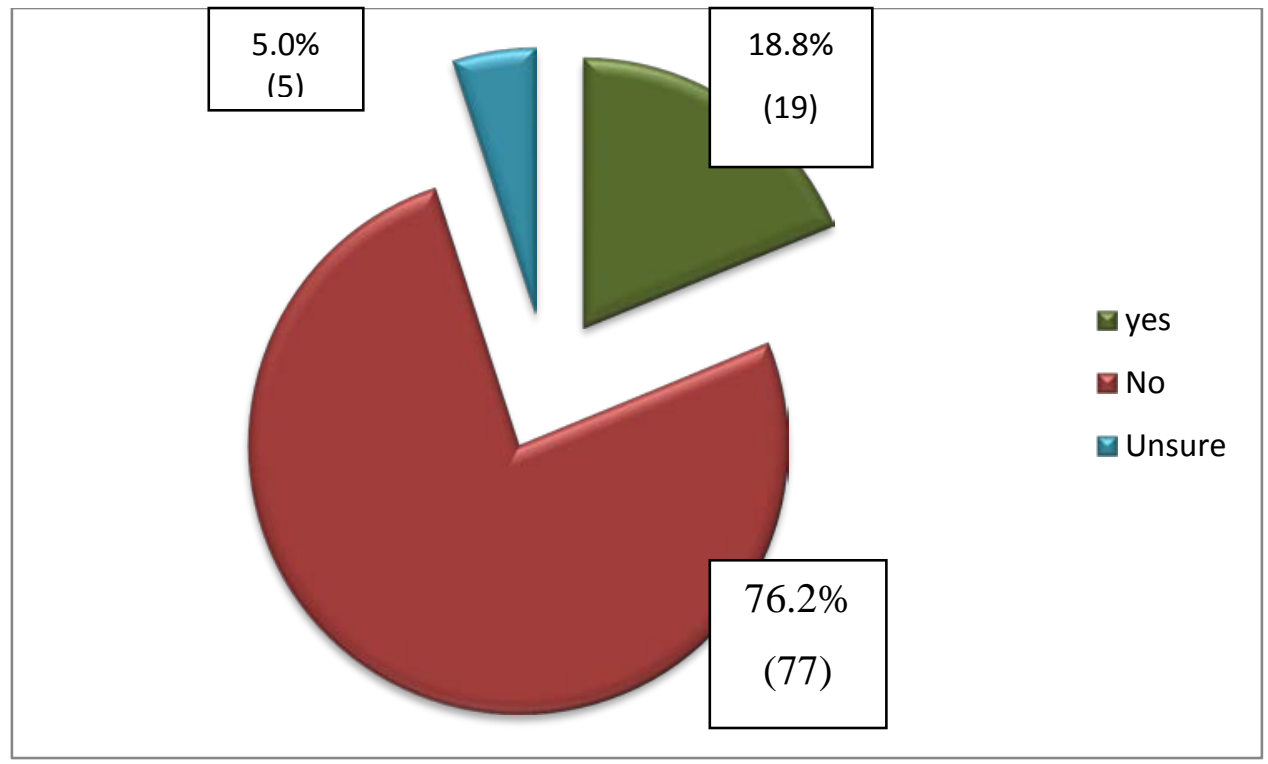


Given the importance of consultation, 47 members saw Community Police Consultative Groups (CPCG) as very or fairly effective and 58 thought CPCGs were hardly or not at all effective (Fig.8). The overwhelming view amongst those police authority members who responded to this particular question was that where police authorities had not adopted new forms and methods to consult with local people but continued with the old consultative arrangements, 77 (76\%) out of 101 responses indicated that the forums did not attract a sufficiently representative audience (Fig.9).

Figure.10 Can accountability be strengthened by electing police authority chairs and members?

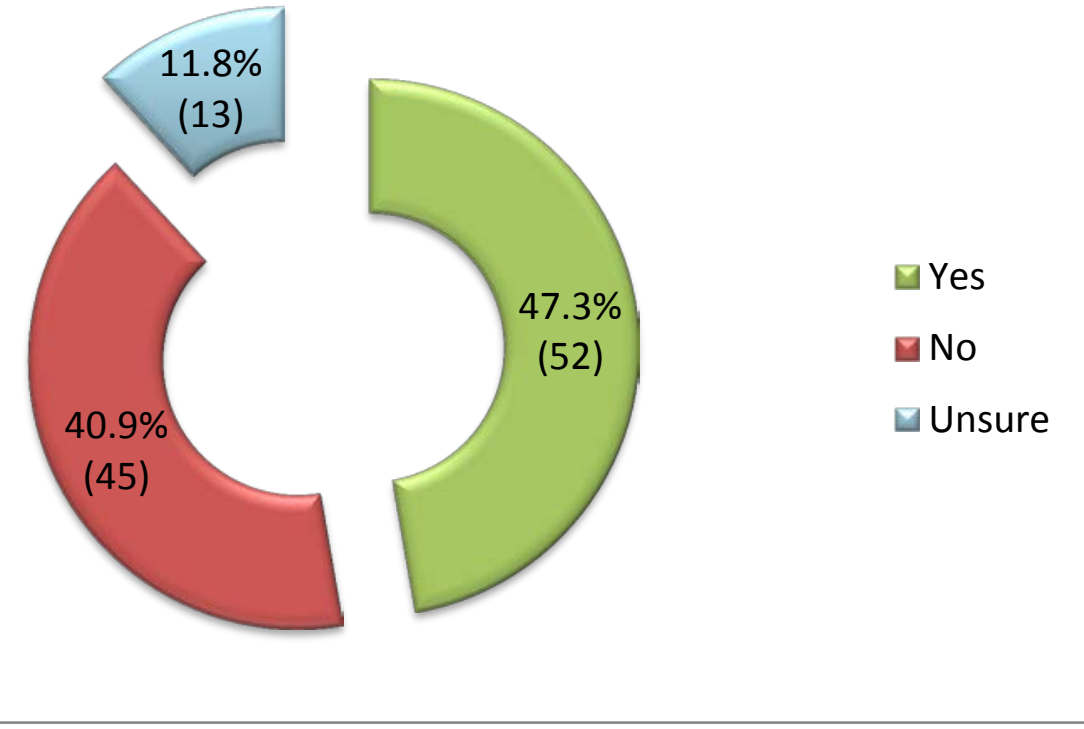

According to Michael Howard (2005), and Loveday and Reid (2003) accountability could be enhanced and supported by the direct election of officials including police authority members and chief constables. The results from this survey have shown that whilst 52 police authority members believed that accountability would be strengthened by electing police authority chairs 
and members (Fig.10), there was no evidence to support the assertion that the process of elections would make the work of the police authority more accountable or indeed more effective. A councillor member of Cumbria Police Authority explained that 'electing members would be stupid and electing chief constables would be equally stupid!' An independent member of the Metropolitan Police Authority also supported this position and explained that elections would not make the police authority more efficient and that she was certain that the elected route would simply maintain the status quo by electing white male professionals.

Figure.11 Would electing members be more democratic than appointments?

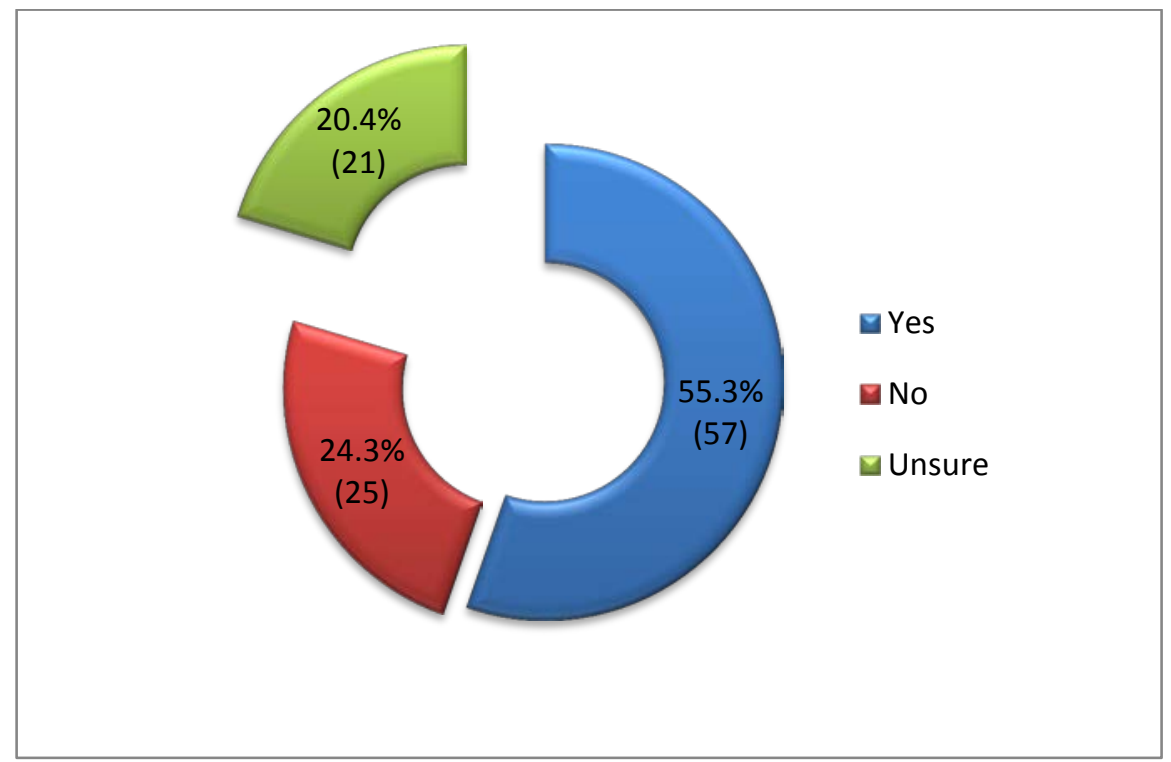

Even though 57 respondents thought that electing police authority members would be more democratic than a recruitment process (Fig.11), the reality is that the merits of appointing through a recruitment process cannot be assessed against that of an electoral one because both processes are attempting to select people using different criteria. The overwhelming majority of interviewees accepted that whilst an elected system would be more 
democratic, selecting members through such a process was far less desirable. One Metropolitan Police Authority member asked:

'Why would you elect a commissioner of police when you do not elect the head of the fire service or the head of any other similar service?'

There is a valid question which is that if all members were elected, the lack of independent non-politically partisan members on police authorities would not be good for local communities.

Figure.12 Would elected chief constables improve accountability and give the local community a greater say?

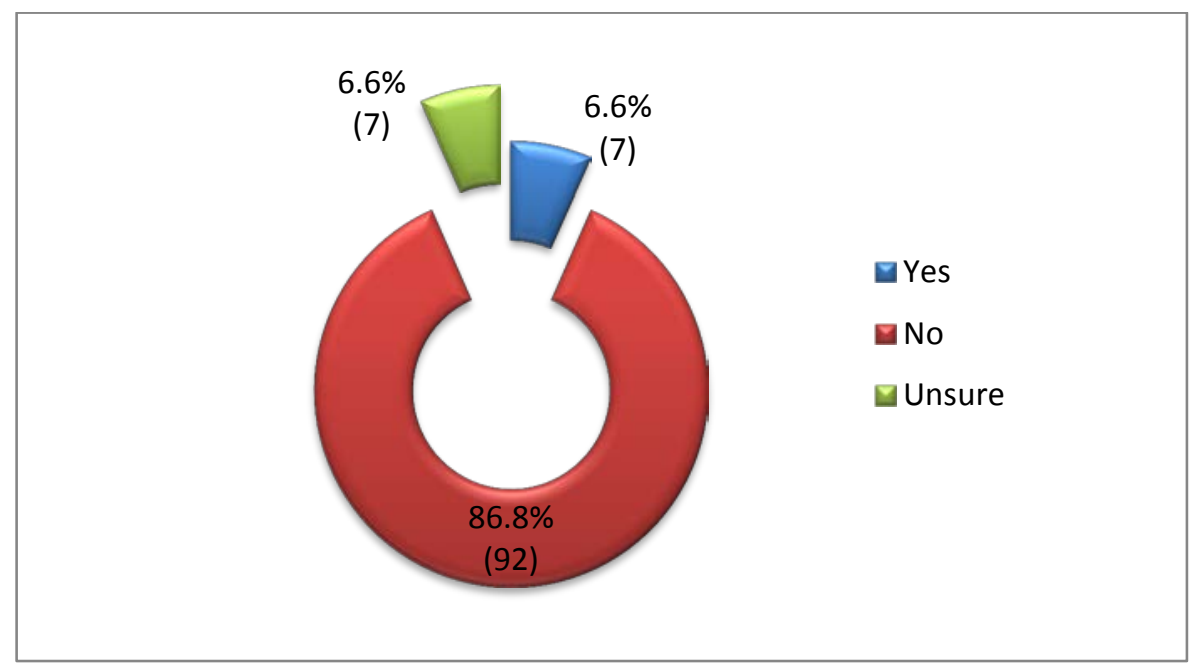

On the prospect of electing chief constables, 92 members (Fig.12) did not believe that elections would improve accountability or increase the voice of the local community and there was consensus that trained professional police were best placed to fill these roles as opposed to professional politicians. Thirty respondents believed that directly electing chief constables would result in a reduction in accountability because this accountability would be to the electorate and not accountability in terms of stewardship (Pyper, 1996), rectification (Mulgan, 2003: 30) or 'the ability to impose a cost' (Keohane, 2002: 479). Forty seven respondents believed elected chief constables would 
have no impact whatsoever and only 13 respondents thought that there would be an increase in accountability.

Figure.13 Do you think the citizen knows about police authorities?

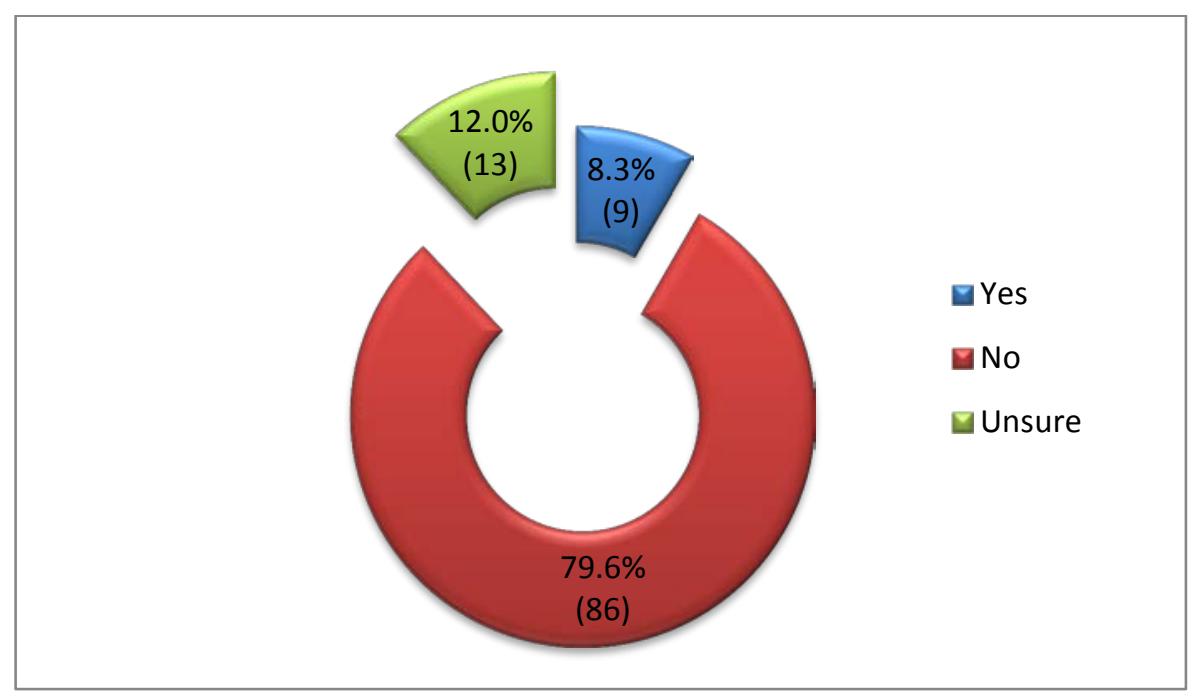

Even though 84 police authority members saw their primary role as representing local people (Fig.5), 86 members felt that the citizen did not know about the police authority (Fig.13) and 13 members were unsure whether or not the citizen knew about them.

Figure.14 Do you think citizens are aware of the distinction between the police service and the police authority?

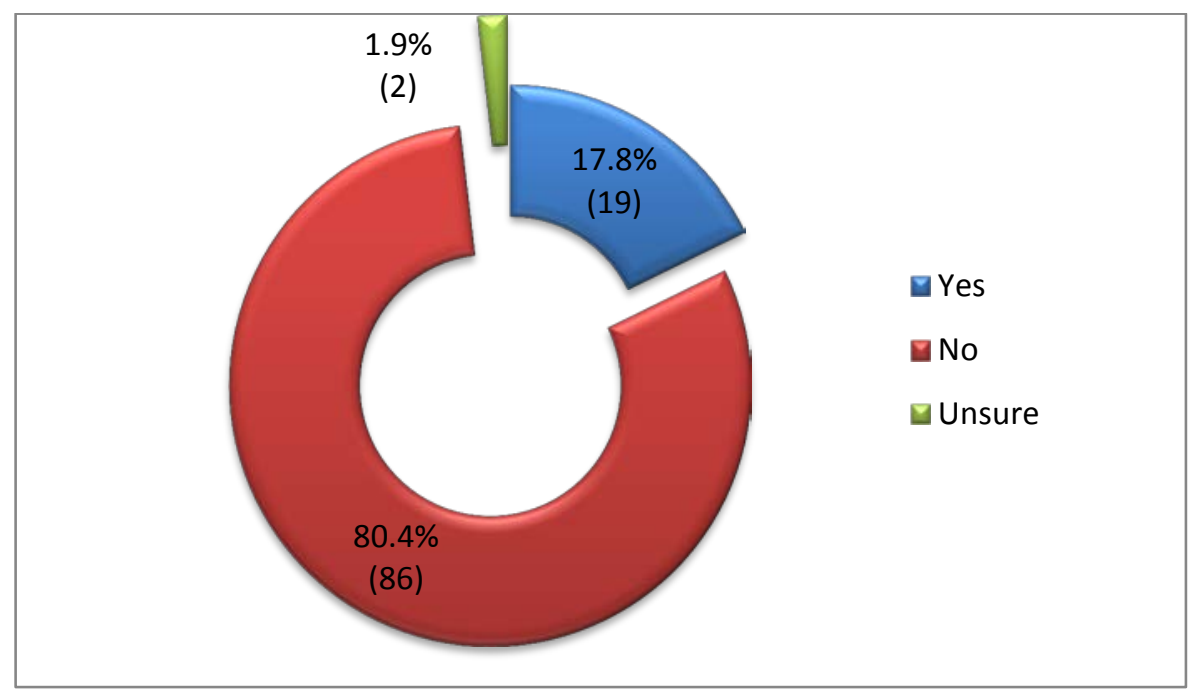


On the question of whether the public were aware of the distinction between the police authority and the police service, the overwhelming view was that 86 out of 107 responses indicated that the distinction was known.

Figure.15 Do national policing plans contradict local priorities?

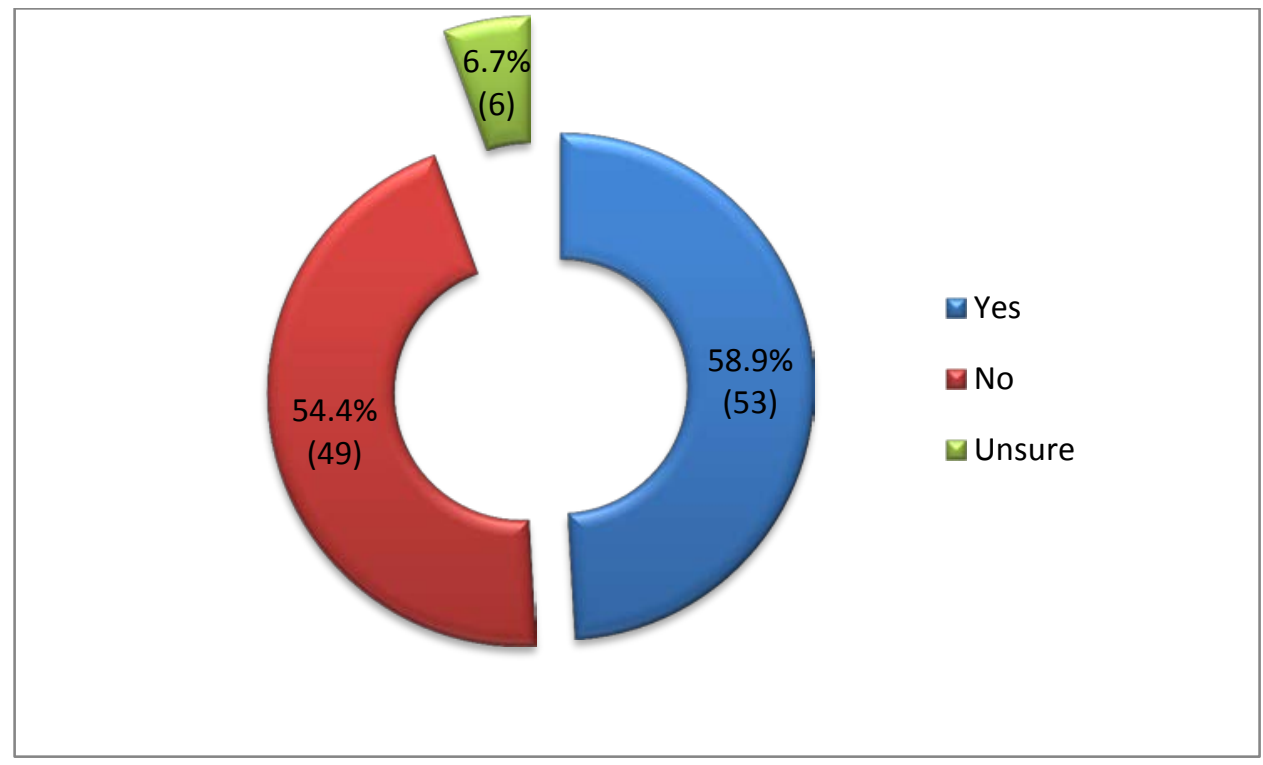

On the question of whether national policing plans were at odds with local priorities, 53 members believed that the plans did impact negatively or contradict local priorities versus 49 who did not (Fig.15). One police authority member explained that in the larger city areas there was no conflict between local and national plans because local plans were heavily dictated by the national agenda - which in itself the member argued served to demonstrate the dominance of the Home Office. The member went on to explain that in the provincial towns there was a real possibility of conflict; for example, if the national concern is with level 2 criminality (cross border issues affecting more than one basic command unit) but the local area is concerned with level 1 criminality (local crimes within a basic command unit). An independent member of Staffordshire Police Authority agreed that this sort of conflict did indeed occur but added that there was some inevitability to this, as some 
issues such as terrorism must be a national priority even though at times its implementation could conflict with local concerns. In general, our findings support the work of Reiner (1991) who found that most chief constables made efforts to develop good working relationships with their police authorities in order to ensure that policing policy was largely in tune with local needs.

Finally, given the complex and sometimes onerous duties placed on police authority members, the level and quality of training they receive should be mentioned. Whilst 96 members had received regular training and 13 did not, 38 members thought that the training they had received was insufficient for the tasks they were expected to undertake; four members were unsure of its usefulness, whilst 25 respondents thought the training was sufficient. Only 29 reported that the training had been good.

\section{Conclusion}

Our starting position is that citizen participation is a prerequisite for the effective delivery of accountable policing because the police do not stand outside of the citizenry but they are at one and the same time the citizen. This has serious consequences for the proposed Police and Crime Commissioners, which are intended to replace police authorities in the near future because they will be specifically charged with representing the wishes of the citizen. However, many police authority members believe that police authorities are not doing enough. A significant number of members questioned their own usefulness and what it was that they and the police authority were doing as far as representation was concerned.

Police authorities need to overhaul their consultative arrangements. Since 2003 police authorities have begun to move away from reliance on traditional police community style meetings to forms of neighbourhood policing. Raine et al. (2006) explained that good accountability depended on good communication processes and they cited that neighbourhood policing was an 
exciting development which if adequately resourced could deliver much in terms of public reassurance.

In 2005, the Association of Police Authorities (APA) established twelve 'Accountability Pilots' led by police authorities and found that some offered valuable opportunities for participation enabling police authority members to hear first-hand how neighbourhood policing was working. It is clear from this research that failure to provide these opportunities will see police authorities become increasingly irrelevant to people's everyday experience of policing.

It is imperative that people know that they can exert influence on policing. One of the key challenges for police authorities is that many people are not aware of their existence. This problem is augmented by the fact that police authority members see themselves as having minimal power to influence policing. Participation through consultation is only meaningful if people's views can be seen to make a difference; it must do more than simply getting people to talk, 'people must decide and do things' (McHugh and Parvin, 2005: 22).

A further challenge arises in ensuring that police consultations are not seen as just the mouthpiece of the police service, simply informing the community of police actions and policy. Police authorities need to develop local links and local knowledge in order to build up trust with the public.

The public in turn needs to demand more from their police authority members - who are in fact their ambassadors. This research has uncovered that police authority members charged with this important responsibility have a low level of trust in their own abilities and the rigour with which they are representing the interests of the wider community. Police authorities can only be effective if members are confident in their own abilities; that they know the questions to ask and have the tools to bring the chief constables to account. 
A Grade 5 civil servant interviewed argued that far too many police authority clerks tended to be fearful of their chief constables, showing an alarming level of deference to them. Where challenges did take place they occurred within very narrow and 'almost' agreed boundaries. This could lead one to conclude that policing by consent actually leaves the public voice outside. It was clear from the research that police authority members lacked sufficient knowledge to be able to ask the right questions. While many also lack the awareness of their legal powers, this research has shown that what police authority members really need is an inquisitive mind and the ability to investigate.

There are also increasing demands on members' time restricting their ability to serve the authority whilst undertaking other work. This can also serve as a disincentive to those who are able to offer much needed expertise on police authorities. In particular there is a deficit of members with professional business and financial expertise to broaden the knowledge base of the police authority.

The shift of power away from police authorities in favour of the Home Office and chief constables does not automatically mean that police authorities are unable to discharge their responsibilities. However, police authorities are constrained by chief constables appealing directly to the Home Secretary and refusing to elaborate or amend reports. This leverage can directly undermine the scrutiny function of the police authority. Chief constables should be responsive to the wishes of their employers - the police authority - and should be limited in their ability to circumvent this responsibility.

Whilst police authorities have a statutory responsibility to consult with the public in order to determine annual local policing priorities, there is no similar responsibility placed on the police service to consult with police authorities. Bob Jones (Chair of the APA) explained that the onus was on police 
authorities to ask questions rather than the police service to tell. A statutory responsibility reversing this and placing the onus on the police service would begin to address this imbalance.

The passage of the Police Reform and Social Responsibility Bill is now completed and it received Royal Assent on $15^{\text {th }}$ September 2011. The Act abolishes police authorities and replaces them with directly elected Police and Crime Commissioners, who have the responsibility of improving police accountability. Except for the Metropolitan Police district - which will have a committee of the London Assembly - Police and Crime Commissioners will be held accountable by Police and Crime Panels made up of locally elected councillors and independent members who will have powers of veto over a commissioner's decisions. Greater transparency of local crime information is also planned with the intention of enabling the public to hold the police to account.

During the Second Reading of the Bill in 2010, Teresa May MP explained that a democratically elected individual was essential in restoring the link between the police and the public. This individual would enable the public to have their say about what their police and crime commissioner is doing in terms of the responsibilities of the police.

Given our evidence of the inability of police authorities to influence, adequately represent, or to challenge the police, it would be easy to conclude that police authorities should be dissolved and have their powers transferred to an elected police and crime commissioner. However, it can be argued that transferring police authority powers to an elected individual will see power and influence concentrated in too few hands. There is also the additional fear that this move will overtly politicise policing (as seen when the Mayor of London - Boris Johnson - withdrew his support for Sir Ian Blair, Commissioner of the Metropolitan Police Service, resulting in him tendering his resignation) 
and render the police more susceptible to corruption and corrupting influences.

These are indeed real fears. What is clear however is that there is no indelible or irrefutable link between corruption and the election of commissioners. There is no evidence that policing would become any more political than it already is. The election of police commissioners would however herald in a different - some argue a better - form of accountability because communities would be empowered to directly hold their chief constables to account.

Currently the relationship between the police service and police authority is in some respects a relationship between collaborators rather than one between a service provider and a regulator. Whilst we accept that joint working is essential, it is at times unclear where and when these lines are drawn. The evidence from our interviews, questionnaires and the literature shows that whilst the functions and the responsibilities of police authorities are important, the current structure and arrangement has resulted in police authorities being unfit for purpose. In fact we found systemic failures in the Metropolitan Police Service's Crime Data Recording. After interviewing a Grade 5 Home Office official, we were informed that even though the Metropolitan Police Authority's report (MPA, 2008:15) clearly identified conflicts of interests and evidence of systemic failures in the workings of the Metropolitan Police Service, the effective real and tangible response from the police authority was grossly inadequate.

One of the benefits of the coalition's proposals for elected commissioners is that the current inherent dislocation and disconnect between local people and the police would be effectively challenged. No longer would bureaucrats and civil servants serve their own purpose by remaining distant from the citizen. Instead we would have elected commissioners serving the interests of the 
'people'. The question is which people? While proposed legislation may see the end of police authorities, the system that replaces them will need to address the challenges raised in this research of reconnecting the citizen with policing. For example, it remains to be seen whether the proposed Police and Crime Panels' ability to veto the decisions of elected commissioners and plans to release more local crime information will help the public directly scrutinise elected commissioners.

There are also other challenges, whilst police authorities were important bodies with important responsibilities, this research does not present a compelling case for maintaining them. Furthermore, there was little evidence that they were delivering a critical service without which the police service would be disadvantaged or rendered useless. One of the litmus tests of the new police and crime commissioners is the degree to which they will make an indelible impression on policing and local communities.

The capacity of police and crime commissioners to sustain an effective and efficient police service, whilst delivering change and increasing accountability, will require detailed attention because the call for greater public accountability dictates that the institutions charged with that responsibility are sufficiently able to deliver. This is important because our research has shown that size matters. For the first time we have identified a distinction based on the size of police authorities in the way they scrutinised, brought to account and managed policing. We identified how smaller police authorities conducted most of their business in full open public meetings and less in committees, whilst larger police authorities did the opposite. However, meetings in smaller authorities were mainly concerned with the police authority's internal business as opposed to the business of scrutinising and calling the police to account. We will be looking with interest at how and if the new arrangements affect this. 


\section{Bibliography}

Association of Police Authorities (APA) (2005) Press Release 22/12/2000, APA Website.

Association of Police Authorities (APA) (2006) [Internet], $<$ [http://www.apa.police.uk/apa] >, Accessed 20 th August, 2006.

Audit Commission (2003a). Trust in the Public Sector, Audit Commission Public Sector Briefing, London.

Audit Commission (2003b) Trust in Public Institutions, Audit Commission/MORI, London.

Baldwin, R. \& Kinsey, R. (1982) Police Powers and Politics, Quartet Books, London.

Boateng, P. (1985) in Baldwin, R \& Kinsey, R (eds.) (1982) Police Powers and Politics, Quartet Books, London: p.238.

Brogden, M. (1977) 'A Police Authority - A Denial of Conflict', Sociological Review, 25(2), pp.325-349.

Coleman, S. (2005) Direct Representation: Towards a Conversational Democracy, IPPR, London.

Critchley, T.A. (1978) A History of Police in England and Wales 900-1966 $\left(2^{\text {nd }}\right.$ ed.), Constable, London.

Dalgleish, D., Docking, M., Myhill, A. \& Yarrow, S. (2003) The Role of Police Authorities in Public Engagement: Home Office Report Online 37/03, Home Office Research, Development and Statistics Directorate, London.

Dalgleish, D., Docking, M., Myhill, A., Sindall, O. \& Yarrow, S. (2003) Involving the Public: The Role of Police Authorities: Home Office Research, Development and Statistics Directorate, London.

Day, P. \& Klein, R. (1987) Accountabilities: Five Public Services, Tavistock Publications Ltd, London.

Docking, M. (2003) Public Perceptions of Police Accountability and Decision Making: Home Office Online Report 38/03, Home Office Research, Development and Statistics Directorate, London.

Elliott, R. \& Nicholls, J. (1996) It's Good to Talk: Lessons in Public Consultation and Feedback, Home Office Police Research Series Paper 22: London.

Hewitt, R. (1996) Routes of Racism: The Social Basis of Racist Action, Trentham Books.

Hoban, M. (2004) Let's Trust the People: Exploring a New Approach to the "Regeneration and Development" of Poor Areas, unpublished PhD thesis, Brunel University, London. 
Home Office (2010) Police Reform and Social Responsibility Bill, B116, Stationary Office, London.

Howard, M. (2005) Leader of the Conservative Party in a Speech in Manchester, Conservative Party, [Internet], $<$ [http://www.manchesterconservatives.com] $>$

Jones, T. \& Newburn, T. (1997) Policing After the Act: Police Governance After the Police and Magistrates' Courts Act 1994, Policy Studies Institute, London.

Jones, T., Newburn, T. \& Smith, D. J. (1994) Democracy and Policing, Policy Studies Institute, London.

Keohane, R. O. (2002) 'Commentary on the Democratic Accountability of Non-Governmental Organizations', Chicago Journal of International Law, 3(2), pp.477-479.

Leicestershire Police Authority (LPA) (2007) [Internet], <[http://www.leicspa.police.uk/about/job-profiles/]>, Accessed on $1^{\text {st }}$ November, 2007.

Loveday, B. \& Reid, A. (2003) Going Local: Who Should Run Britain's Police, Policy Exchange, London.

Lustgarten, L. (1986) The Governance of Police, Sweet and Maxwell, London.

Marshall, G. (1978) Police Accountability Revisited, in Butler, D. Attitudes to Crime and Criminal Justice: Findings from the 1998 British Crime Survey, Home Office Research Study 200, London.

May, T. (2010) Police Reform and Social Responsibility Bill - Second Reading, $13^{\text {th }}$ December, Parliamentary Debates, Commons, Vol. 520, cols. 707-719

McHugh, D. \& Parvin, P. (2005) Neglecting Democracy; Participation and Representation in $21^{\text {st }}$ Century Britain: Hansard Society.

Mulgan, R. (2003) Holding Power to Account: Accountability in Modern Democracies, Palgrave MacMillan, New York.

Metropolitan Police Authority (2008) Crime Data Recording Scrutiny Report, Final Report.

Oliver, I. (1987) Police, Government and Accountability, Macmillan Press, London.

Parekh Report (2002) The Future of Multi-Ethnic Britain, Runnymede Trust, London.

Policy Studies Institute (PSI) (1997) Independent Committee of Inquiry Into the Role and Responsibility of the Police, PSI, London.

Pyper, R. (ed.) (1996) Aspects of Accountability in the British System of Government, Tudor Business Publishing, Merseyside. 
Raine, J., Dunstan, E. \& Patrick, R. (2006) Enhancing Accountability in Local Policing: Lessons from Twelve Police Authority Projects, Association of Police Authorities (APA), London.

Reiner, R. (1991). Chief Constables: Bobbies, Bosses or Bureaucrats? Clarendon Press, Wutton-under-Edge.

Reiner, R. (1992) The Politics of the Police, Harvester Wheatsheaf, Hemel Hempstead.

Reiner, R. (2000) The Politics of the Police, $3^{\text {rd }}$ edition, Oxford University Press, New York.

Scarman Report (1986) The Brixton Disorders: 10-12 April, 1981, Pelican Books, Harmondsworth.

Stephens M. (1988), 'Policing the Critical Issues' in National Employment Panel: (2005) Enterprising People Enterprising Places. 